\title{
Seasonally flooded stepping stones: emerging diversity of small mammal assemblage in the Amazonia-Cerrado ecotone, central Brazil
}

\author{
Rita Gomes Rocha ${ }^{1,2,3^{*}}$, Eduardo Ferreira', Iracy Coelho Menezes Martins ${ }^{3}$, Leonora Pires Costa ${ }^{2}$ \\ and Carlos Fonseca'
}

\begin{abstract}
Background: Seasonally flooded natural forest fragments, so-called ipucas, in the Araguaia alluvial plain of the state of Tocantins, central Brazil, represent a peculiar landscape that is poorly surveyed. This study considers the diversity in the small mammal assemblage and the zoogeographical patterns of this assemblage when compared to 30 other study sites in Brazil.

Results: 'Ipucas' harbour species adapted to disturbed habitats that are common in fragmented landscapes and endemic species of the Cerrado. However, they also constitute the most central-eastern distribution limit of one typical Amazonian species. These fragments are closely related to the central-western region of Brazil, in the Amazonia-Cerrado ecotone, which lies in the so-called arc of deforestation.

Conclusions: Our results reinforce the idea that the habitat mosaic found in the Araguaia alluvial plain has an important role in promoting the high biodiversity of this area and that natural forest fragments may act as a refuge and food resource for several species. These fragments may also constitute essential stepping stones for small mammal species within agricultural landscapes. Further studies are essential to better understand small mammal communities inhabiting natural forest fragments in the Araguaia alluvial plain, and these will support in assessing the future of this fauna and, thereby, help to establish future conservation practices in this area.
\end{abstract}

Keywords: Araguaia alluvial plain; Arc of deforestation; Didelphimorphia; 'Ipucas'; Rodentia

\section{Background}

The flora and fauna of two major neighbouring biomes of South America, Amazonia and Cerrado, overlap in a broad ecotonal area extending along a northeast to southwest axis in the states of Maranhão, Pará, Tocantins and Mato Grosso in central Brazil (Ackerly et al. 1989; Lacher and Alho 2001; Oliveira-Filho and Ratter 2002; Bezerra et al. 2009; Rocha et al. 2011). This transition from Amazonian deciduous and semi-deciduous forest to the savannah-like vegetation of Cerrado, which varies from grasslands to dense woodland, is mainly related to soil conditions (Ratter

\footnotetext{
*Correspondence: rgrocha@ua.pt

'Departamento de Biologia and CESAM, Universidade de Aveiro, Campus de Santiago, 3810-193 Aveiro, Portugal

2Laboratório de Mastozoologia e Biogeografia, Departamento de Ciências Biológicas, Universidade Federal do Espírito Santo, Av. Marechal Campos 1468, Maruípe, 29043-900 Vitória, Espírito Santo, Brasil

Full list of author information is available at the end of the article
}

1992). The Araguaia River lies in this transition, which is mostly characterized by the presence of alluvial forests and floodplain grasslands that are strongly influenced by the seasonal river-flooding regime (Oliveira-Filho and Ratter 2002).

Seasonally flooded natural forest fragments, regionally known as 'ipuca' or 'impuca' (Eiten 1985), are found in the landform depression swales of the middle Araguaia alluvial plain in central Brazil (Martins et al. 2002; Martins et al. 2008). These fragments represent a peculiar landscape when compared to surrounding vegetation types, which are mainly composed of 'varjão' - a seasonally flooded non-forested terrain (Eiten 1985; Martins et al. 2006; Martins et al. 2008). Ipucas are composed of the flora species of Amazonia, Atlantic Forest and Cerrado and, floristically, are closely related to the gallery forest of the central-western region of Brazil (Martins et al. 2008). 
Despite occurring as patches, Martins et al. (2008) suggested that these ipucas may act as stepping stones between riparian forests and the remaining forested areas of the Cerrado, which should favour the dispersal and conservation of the wildlife they harbour.

Small mammals, comprising both marsupials and rodents, are a common group in both forest and open areas (e.g. Carmignotto 2005; Gardner 2008; Paglia et al. 2012). Their richness and diversity are related to the habitat heterogeneity and complexity and have been used to understand both ecological and biogeographic patterns of Cerrado (e.g. Carmignotto 2005). Several studies have been conducted to understand the impact of fragmentation on small mammal communities in Cerrado (e.g. Bonvicino et al. 2002; Cáceres et al. 2010; Gheler-Costa et al. 2012; Napoli and Cáceres 2012), but ecological studies focusing on this group in natural forest fragments, or ipucas, in the Araguaia alluvial plain are lacking. This is still more relevant given the importance of this region, since it was considered a priority area for conservation of the Cerrado biodiversity (e.g. Cavalcanti and Joly 2002).

This study was aimed at assessing the diversity of the small mammal assemblage in ipucas and the zoogeographical patterns of this assemblage when compared to 30 additional study sites in Brazil. First, we evaluate the composition and richness of small mammal species in these natural fragments. Then, by comparing small mammal species assemblages among these fragments and other study areas distributed throughout the Cerrado and adjacent biomes, we investigate the affinities of these seasonally flooded natural forest fragments. We test the hypothesis that the small mammal species composition in ipucas is similar to that in gallery forests of the central-western region of Brazil, as suggested in studies of floral species composition (Martins et al. 2008). Furthermore, we discuss the conservation importance of these natural forest fragments located in the Amazonia-Cerrado ecotone of central Brazil.

\section{Methods}

\section{Study area and sampling design}

Small mammals were collected in natural forested fragments, in the pristine area of the Cerrado sensu strictu matrix and in the irrigation channels of a private ranch, Fazenda Lago Verde (FLV), municipality of Lagoa da Confusão, state of Tocantins, central Brazil (Figure 1). Fazenda Lago Verde is an 8,000-ha private ranch that is managed for artificially irrigated crop production (rice, maize, bean and soybean). It is located along the Urubu and Lago Verde Rivers. About 70\% of its area consists of pristine Cerrado sensu lato physiognomies, ranging from 'cerradão' (dense savanna woodland) to open scrublands, grasslands and 'varjões' (Oliveira-Filho and Ratter 2002). Natural forest fragments, or ipucas, occur within agricultural, Cerrado and varjões matrices at FLV. The regional climate is tropical, with a rainy season from October to April and a dry season from May to September (INMET 2011). Ipucas periodically flood during the rainy season, which makes them important elements in draining and

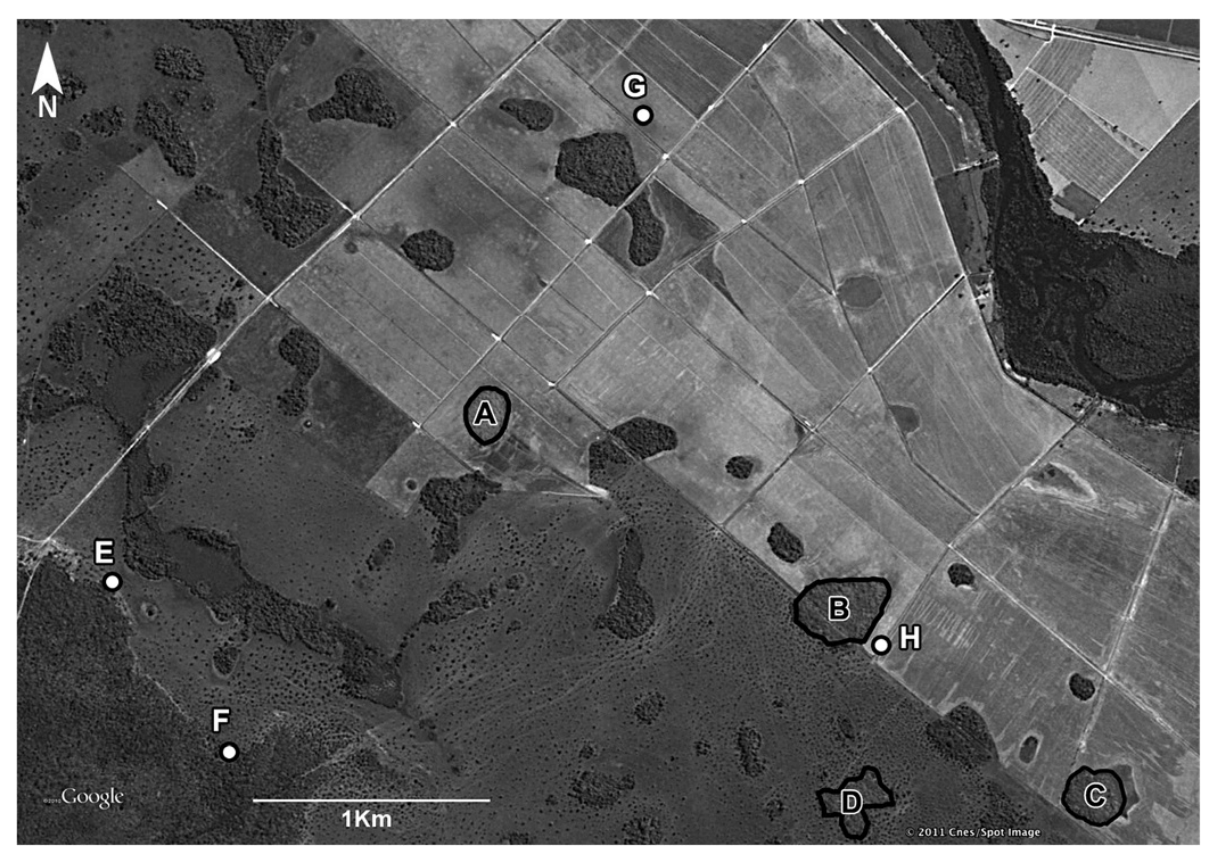

Figure 1 Detailed view of the study area in the Fazenda Lago Verde, state of Tocantins. Natural forest fragment sampled (A to D) and additional sampling points at Cerrado ( $E$ to F) and along irrigation channels ( $\mathrm{G}$ to H) are shown. Geographical information of the study area is given in Figure 4 (sampling site 4) and Additional file 1. Source: Google Maps. 
connecting several streams of the Araguaia alluvial plain (Martins et al. 2006).

Four natural fragments were selected in the study area, according to their surrounding matrices: agricultural matrix (ipuca A), agricultural and Cerrado frontier (ipucas $B$ and $C$ ) and Cerrado matrix (ipuca D). From June to November 2008, each ipuca was sampled three times, except for ipuca $C$, which was sampled just once. Each sampling period comprised seven consecutive trapping nights. Each fragment, except ipuca $C$, was sampled with a transect of $1630 \mathrm{~L}$ pitfalls with drift fences, a transect with 22 Sherman traps $(45 \times 12.5 \times 14.5 \mathrm{~cm})$ and 10 Tomahawk traps $(45 \times 21 \times 21 \mathrm{~cm})$ placed on the ground and a transect with 4. Sherman traps and 4 Tomahawk traps placed in the understorey. Ipuca $\mathrm{C}$ was sampled only with Sherman and Tomahawk traps at the ground (32) and understorey (8) levels. Four additional transects (E to $\mathrm{H}$ ) with 22 Sherman and 10 Tomahawk traps were sampled only during a seven-night period. These were established in the Cerrado sensu strictu matrix (E to F) and near irrigation channels ( $\mathrm{G}$ to $\mathrm{H}$ ) at FLV. Live traps were baited with peanut butter and pineapple and were checked daily. The first series of individuals of each species were collected and prepared as voucher specimens. The remaining specimens were identified to species level, ear tagged, measured, weighed and then released. Voucher specimens have been deposited in the mammal and tissue collections at Universidade Federal do Espírito Santo (UFES), Vitória, Brazil (see details in Rocha et al. 2011). Fieldwork was done under the permits of Federal (Instituto Chico Mendes de Conservação da Biodiversidade-ICMBio, permits 200/2006 and 14307-1) and State (Naturatins, permits: 019/2006 and 001/2008) Conservancy Agencies.

\section{Species richness, diversity and composition}

The small mammal communities of natural forest fragments in the Araguaia alluvial plain were described based on the number of individuals $(n)$ of each species, on the species richness $(S)$ and diversity $\left(H^{\prime}\right.$ and $E$ ) for each sampling point. Diversity, which simultaneously accounts for species richness and the relative contribution of each species, was estimated with the Shannon-Wiener index $\left(H^{\prime}=-\sum_{p i} \ln p i\right.$, where $p i$ is the proportion of species $i)$ and the equitability index $\left(E=\mathrm{e}^{\mathrm{H}} / \mathrm{S}\right)$ (Hayek and Buzas 1997). The total number of captured individuals was also used to calculate the trap success, which is a standardized measure for trapping effort (trap success = $n \times 100$ / trap effort). Small mammal species were classified according to their geographic distribution (Gardner 2008; IUCN 2013) and also their form of locomotion (Emmons and Feer 1997; Paglia et al. 2012).

Individual-based species accumulation and Chao 1 richness estimator curves were produced using the software EstimateS version 9.1.0 (Colwell 2013). Species accumulation curve corresponds to the mean among 100 independent runs with random sampling of individuals from the reference sample. Chao 1 richness estimator was estimated according to Chao (1984).

\section{Zoogeographical patterns analysis}

To compare small mammal species assemblages, we selected 30 faunistic study sites from Cerrado, the AmazoniaCerrado ecotone, Amazonia, Pantanal and the Atlantic Forest-Cerrado ecotone (see Additional file 1 for further geographic information on selected sites). Taxonomy was updated with Wilson and Reeder (2005), Weksler (2006) and Gardner (2008) to avoid incongruities. Species identified only to the genus level were excluded from the analyses, as well as Oryzomys capito and Oecomys bicolor, which represent composite species. The current geographical distributions of small mammal species were confirmed based on several authors (Gardner 2008; Bonvicino et al. 2008; Paglia et al. 2012; IUCN 2013).

A binary matrix was constructed based on the presence (1) or absence (0) of all the small mammal species occurring in the selected sampling sites and in the ipucas. A Bray-Curtis similarity matrix was created in PRIMER v6 (Clarke and Gorley 2006). This matrix was used to construct a dendrogram using the CLUSTER routine implemented in PRIMER v6 (Clarke and Gorley 2006), which performs group average linkage in the hierarchical agglomerative clustering algorithm. We used the SIMPROF test, a similarity profile routine, which tests for the presence of sample groups in an a priori unstructured set of samples (Clarke et al. 2008).

\section{Results}

Small mammal richness, diversity and composition

An effort of 4,704 trap nights yielded 116 captures of 12 species at FLV ( $\approx 2.5 \%$ trap success). The diversity estimate based on the total captured assemblage was $H^{\prime}=1.96$ and $E=0.79$ (Table 1). Small mammal species captured in the FLV included three didelphid marsupials, eight cricetid rodents and one echyimid rodent (Table 1). Of those species, five were exclusively captured in the natural forested fragments (Gracilinanus agilis, Philander opossum, Hylaeamys megacephalus, Rhipidomys ipukensis and Makalata didelphoides), and two were only captured in the Cerrado and agricultural matrix (Didelphis albiventris and Pseudoryzomys simplex) (Table 1). Although species number grows steadily, species accumulation curve showed a tendency to stability (Figure 2).

Natural forest fragments had the highest species richness $(S=10)$ and diversity $\left(H^{\prime}=1.69\right)$, but the trap effort was also the highest (Table 1). The cerrado matrix (E to F) had higher species richness $(S=5)$ and diversity $\left(H^{\prime}=1.49\right)$ than the agricultural matrix (G to $\mathrm{H}, S=3$ and $H^{\prime}=0.87$ ) (Table 1). 
Table 1 Species recorded at Fazenda Lago Verde, state of Tocantins

\begin{tabular}{|c|c|c|c|c|c|c|}
\hline & Ipucas (A to D) & Cerrado ( $E$ to $F$ ) & Agricultural (G to $\mathrm{H}$ ) & Total & Locomotion & Distribution \\
\hline \multicolumn{7}{|l|}{ Species } \\
\hline Didelphis albiventris & - & 1 & - & 1 & Arb/Terr & Cer/Caa/AtlF \\
\hline Gracilinanus agilis & 40 & - & - & 40 & Arb & $\mathrm{Am} / \mathrm{Cer} / \mathrm{Caa} / \mathrm{AtlF}$ \\
\hline Philander opossum & 3 & - & - & 3 & Arb/Terr & Am \\
\hline Calomys tocantinsi & 5 & 2 & 11 & 18 & Terr & Eco/Cer \\
\hline Holochilus sciureus & 1 & - & 2 & 3 & Semi-Aqua & Am/Cer/Caa \\
\hline Hylaeamys megacephalus & 6 & - & - & 6 & Terr & $\mathrm{Am} / \mathrm{Cer}$ \\
\hline Necromys lasiurus & 2 & 3 & - & 5 & Terr & $\mathrm{Am} / \mathrm{Cer} / \mathrm{Caa} / \mathrm{AtlF}$ \\
\hline Oecomys sp. & 6 & 1 & - & 7 & Arb & Eco \\
\hline Oligoryzomys fornesi & 3 & - & 4 & 7 & Terr & Cer/Caa \\
\hline Pseudoryzomys simplex & - & 1 & - & 1 & Terr & Cer/Caa \\
\hline Rhipidomys ipukensis & 22 & - & - & 22 & Arb & Eco \\
\hline Makalata didelphoides & 3 & - & - & 3 & Arb & $\mathrm{Am}$ \\
\hline N & 91 & 8 & 17 & 116 & & \\
\hline Trap effort & 3808 & 448 & 448 & 4,704 & & \\
\hline Trap success (\%) & 2.4 & 1.8 & 3.8 & 2.5 & & \\
\hline S & 10 & 5 & 3 & 12 & & \\
\hline$H^{\prime}$ & 1.69 & 1.49 & 0.87 & 1.96 & & \\
\hline E & 0.74 & 0.93 & 0.80 & 0.79 & & \\
\hline
\end{tabular}

Number of captured individuals ( $n$ ) of small mammal species in each of four natural forest fragments (A to D), in the Cerrado sensu strictu matrix (E to F) and in the irrigation channels in the agricultural matrix ( $\mathrm{G}$ to $\mathrm{H})$, with trap effort and success, and species richness (S) and Shannon-Wiener diversity index ( $\left.H^{\prime}\right)$ for each sampling point. Form of locomotion (Arb, arboreal; Terr, terrestrial; Semi-aqua, semi-aquatic) and geographic distribution of small mammal species in Brazil (Am, Amazonia; Cer, Cerrado; Eco, ecotone Amazonia-Cerrado; AtIF, Atlantic Forest; Caa, Caatinga).

Two arboreal species, G. agilis and R. ipukensis, were the most abundant species in the natural forest fragments (Table 1). The ground-dwelling Calomys tocantinsi was the most abundant species in open areas (Table 1). Most of the species captured at the Araguaia alluvial plain are widely distributed, occurring in several biomes, such as $G$. agilis, H. megacephalus and Necromys lasiurus (Table 1). Two species that occur exclusively in the ecotone between Amazonia and Cerrado, R. ipukensis and Oecomys sp., were also captured in the ipucas (Table 1).

\section{Zoogeographical patterns}

A matrix of the 31 sampling sites yielded a total of 103 species of small mammals, including 29 didelphid marsupials, 53 cricetid rodents and 21 echyimid rodents.

The dendrogram from the cluster analysis of the similarity among sampling sites revealed five main groups (Figure 3). Three sampling sites (20, 22 and 29) did not group with any other site (Figure 3). Sampling sites 20 and 22 are located in Pantanal, state of Mato Grosso do Sul. Sampling site 29 is located in the south-eastern Atlantic Forest-Cerrado ecotone, state of Minas Gerais (Figure 4).

Amazonian sites (group I: 1 and 2) from the state of Pará clustered separately from all other sites (Figures 3 and 4). Group II mainly included sites not only from the Amazonia-Cerrado ecotone (3 to 6 and 15 to 18) but also a site from Cerrado (7 and 9) and from the Atlantic Forest-Cerrado ecotone (19) (Figures 3 and 4). There were three other clusters within group II, including sites from the states of Tocantins (a: 3 to 7), Mato Grosso (b: 15 to 18) and Goiás and Mato Grosso do Sul (c: 9 and 19) (Figures 3 and 4). Ipucas also clustered in group II (locality 4, Figures 3 and 4).

Group III included sites from south-western Cerrado, state of Mato Grosso do Sul (21, 23 to 24) (Figures 3 and 4). Group IV included sites from central and north-eastern Cerrado (Figures 3 and 4). There were two clusters within group IV: one that included north-eastern sites from the states of Piauí, Tocantins, Bahia and Minas Gerais (d: 8, 25, 27 to 28) and another that included the central plateau, Distrito Federal and Goiás (e, 11 to 14). One sampling site (26), which is located in a Caatinga moist forest enclave, state of Bahia (Figure 4), was included in group IV but did not cluster with any other sampling site. Group V included samples from southern Cerrado, states of Goiás (10) and São Paulo (30 to 31) (Figures 3 and 4).

\section{Discussion}

Small mammal richness, diversity and composition

The species richness recorded in ipucas and their matrix (12 species) is relatively low compared to those of other studies carried out in the ecotonal area between Cerrado 


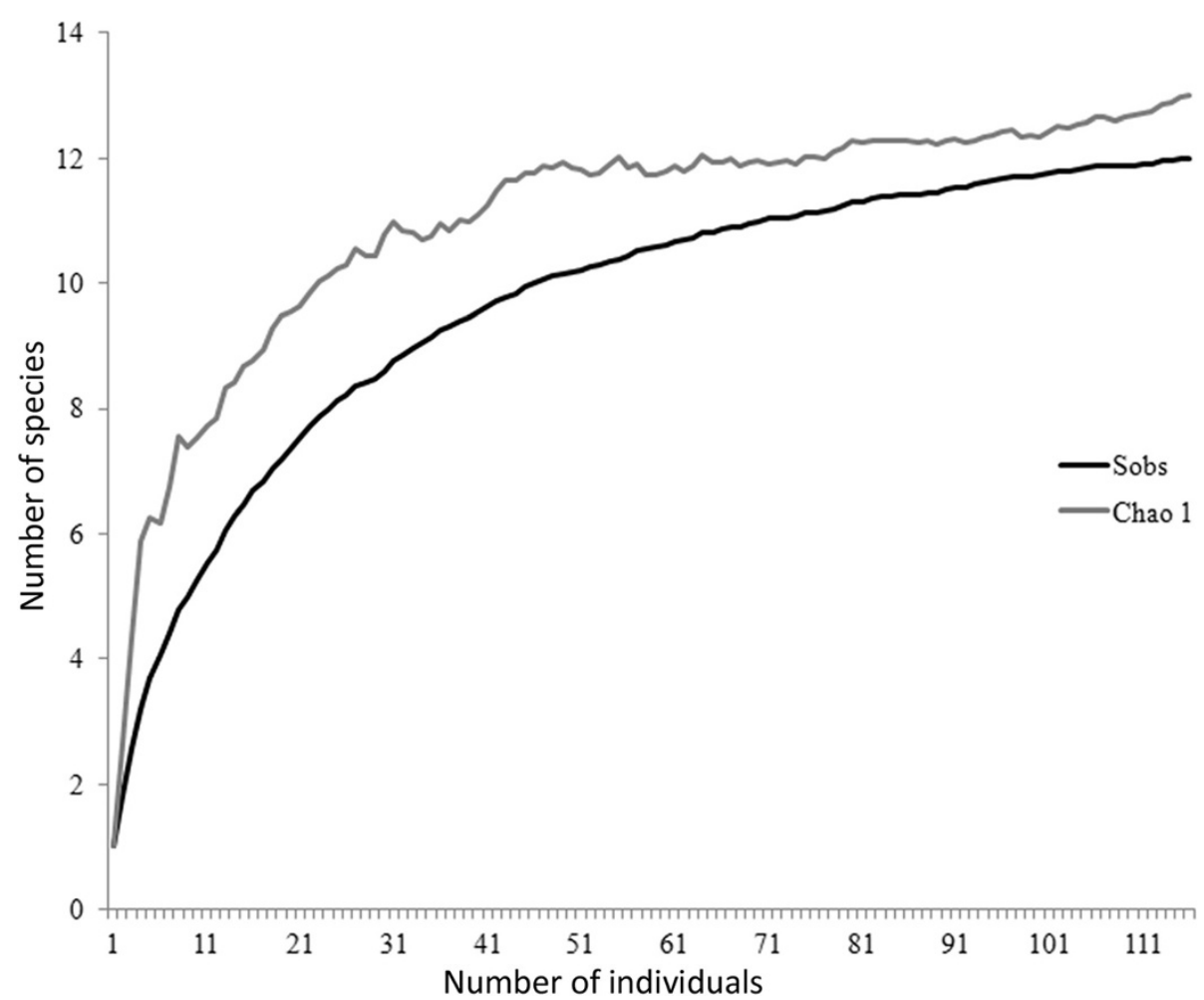

Figure 2 Species accumulation curve and Chao 1 richness estimator for the study area. Accumulation curve was smoothed after 100 randomizations and scaled by individual.

and Amazonia, where it varied between 13 and 22 species (Bonvicino et al. 1996; Lacher and Alho 2001; Lambert et al. 2006; Bezerra et al. 2009; Rocha et al. 2011). However, it lies within the range of other studies carried out in the Cerrado, where species richness varied from 7 to 22 species (e.g. Bonvicino et al. 2002; Rodrigues et al. 2002; Bonvicino and Bezerra 2003; Carmignotto 2005; Bonvicino et al. 2005; Paglia et al. 2005; Ribeiro and Marinho-Filho 2005; Carmignotto and Aires 2011). Moreover, species richness in the

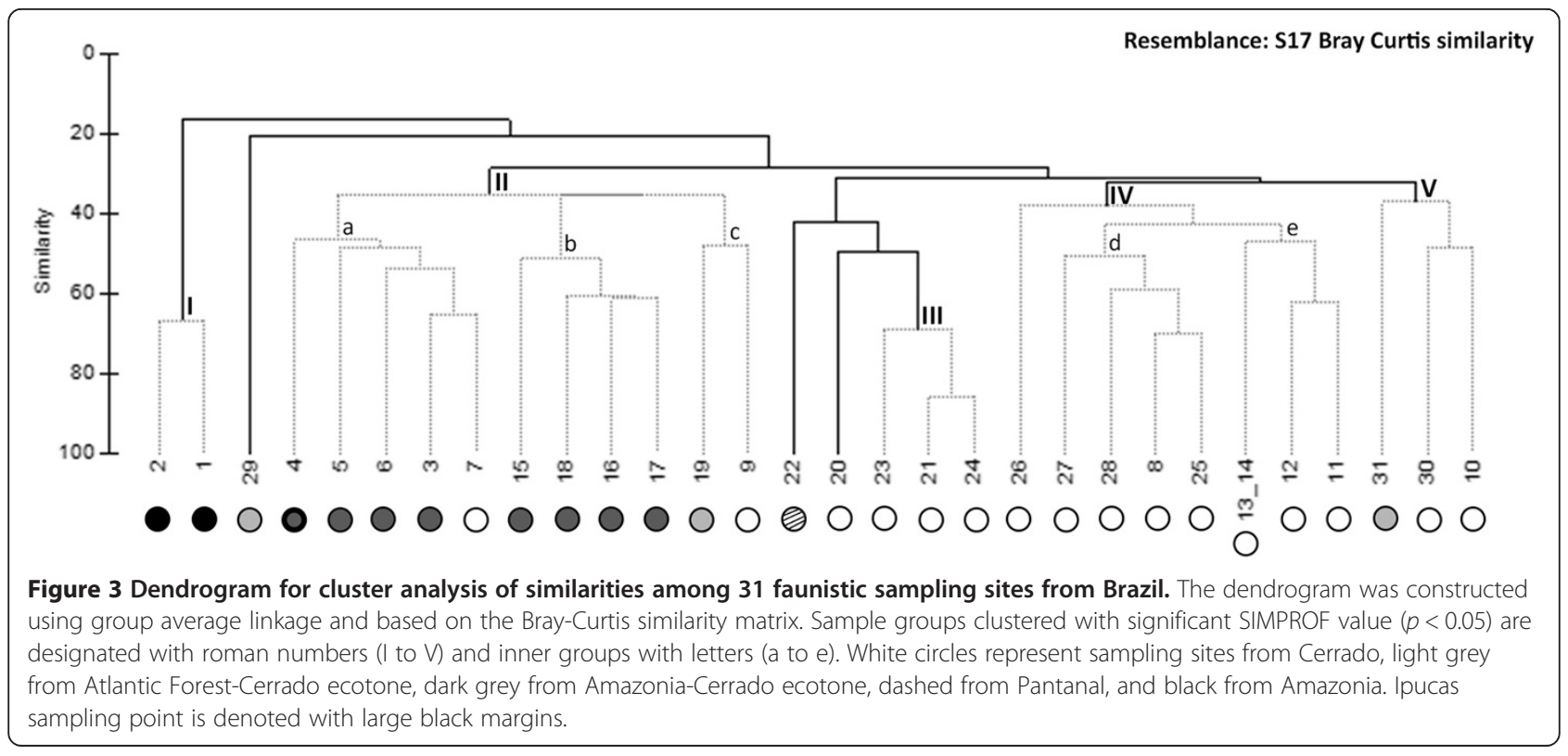




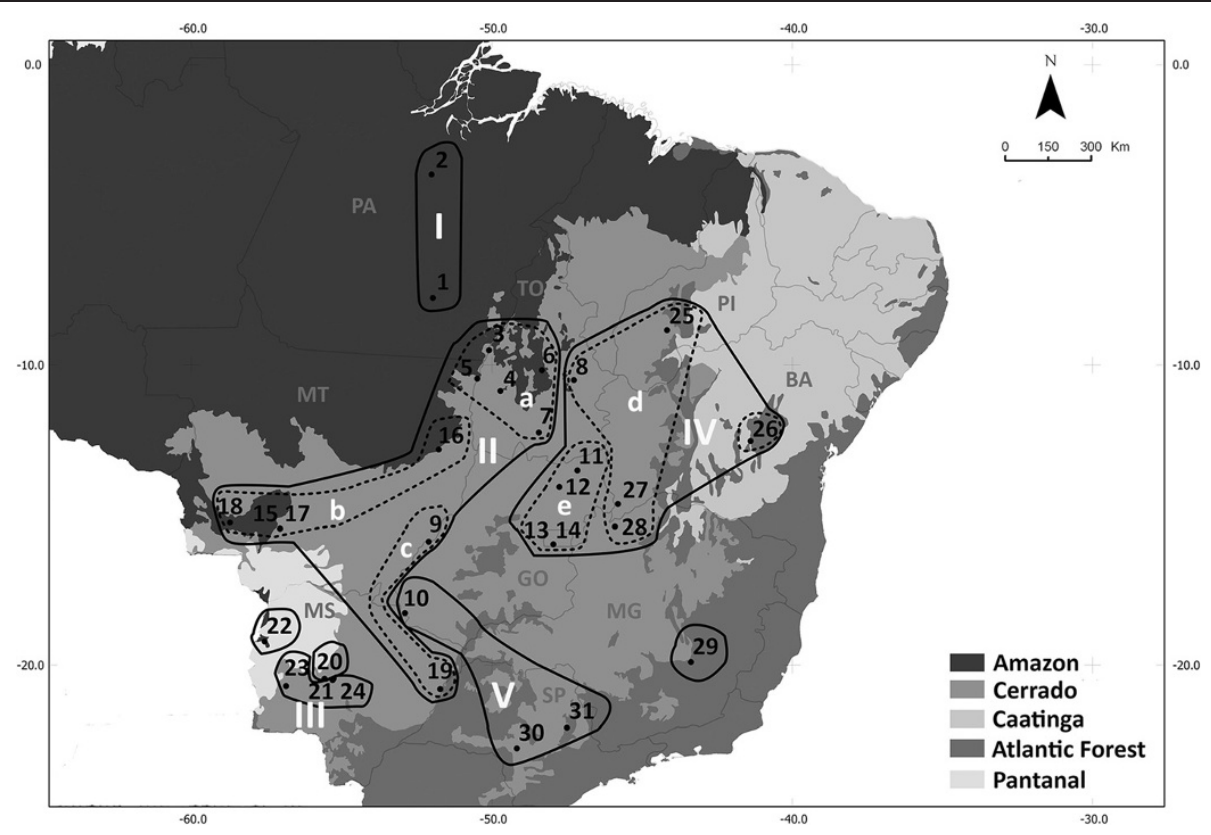

Figure $\mathbf{4}$ Map of $\mathbf{3 1}$ faunistic sampling sites with the geographical subsets based on the dendogram results. Main groups are delimited with full lines (I to $V$ and 20, 22 and 29) and inner groups with dashed lines (a to c). These groups were clustered with significant SIMPROF values (see Figure 3). Biomes are defined in a grey scale and for Brazilian states are indicated with abbreviations (see Additional file 1).

study area can grow steadily with additional sampling effort in the region (Figure 2).

The marsupial G. agilis was the most common species captured in ipucas. In contrast, P. opossum was only captured three times in ipucas, and $D$. albiventris was only captured once in the Cerrado matrix. Thus, there is an apparent scarcity of marsupial species in these natural forested fragments, despite the fact that several other species of marsupials (e.g. Caluromys philander, $D$. marsupialis, Marmosa murina, Marmosa demerarae) have been captured in gallery forests of the Araguaia River (Bezerra et al. 2009; Rocha et al. 2011). D’Andrea et al. (2007) argued that the absence of marsupials from agro-ecosystems in the Atlantic Forest is probably related to the lack of major continuous forests, which are the favoured habitats of several didelphid species (Emmons and Feer 1997). This pattern was also reported by BarrosBattesti et al. (2000) in isolated remnants of Atlantic Forest. On the other hand, Cáceres et al. (2010) argued that marsupials sometimes dominated in abundance or richness in the smaller fragments of woodland and gallery forests in Cerrado, G. agilis being one of the species that contribute to this dominance (Cáceres et al. 2010; Napoli and Cáceres 2012). Although G. agilis is an arboreal species, like several other didelphid species (Emmons and Feer 1997), its small size and its broad habitat tolerance (Cáceres et al. 2010) make it more adapted to fragmented habitats, such as ipucas.

Three rodent species found in ipucas are not only endemic to Cerrado but have also been found in the ecotone between this biome and Amazonia (Bezerra et al. 2009; Rocha et al. 2011). Although little is known about their ecology since two have only recently been described $(C$. tocantinsi Bonvicino et al. 2003 and R. ipukensis Rocha et al. 2011) and one is still an undescribed species (Oecomys sp.), endemic small mammals tend to occupy native vegetation, as argued by Umetsu and Pardini (2007). Widely distributed species, such as $H$. megacephalus and $N$. lasiurus, were also captured in these natural forest fragments. Such species are presumably less selective and adapted to more disturbed habitats (Marinho-Filho et al. 2008; Percequillo et al. 2008). However, H. megacephalus has more frequently been captured in the Araguaia gallery forests (Bezerra et al. 2009; Rocha et al. 2011), which is concordant with the results of Cáceres et al. (2010). These authors also found a different community of small mammals in gallery forests than that occurring in the fragmented landscape of the Cerrado. On the other hand, $N$. lasiurus was exclusively captured in the Cerrado and agricultural matrix, since this is a typical species of open areas, grasslands and forest borders (Marinho-Filho et al. 2008). Makalata didelphoides, a typical Amazonian species, which inhabits seasonally flooded tropical forests and secondary forests (Emmons and Feer 1997), was also captured in ipucas, now constituting the most central-eastern limit of the distribution of this species. Bezerra et al. (2007) have already expanded the geographic distribution of another typical Amazonian species (Dactylomys dactylinus) to gallery forest patches of the Araguaia-Tocantins basin, in central Brazil. 
Natural forest fragments at the Araguaia alluvial plain harbour a small mammal fauna that is dominated by small-sized arboreal species, such as G. agilis, Oecomys sp. and $R$. ipukensis. These natural fragments are seasonally flooded (Eiten 1985; Martins et al. 2008), which may constitute an important abiotic factor that determines their faunal composition. It has been shown that the faunal assemblages of flooded forests differ from that of unflooded forests (e.g. Haugaasen and Peres 2005; Beja et al. 2009; Ramos Pereira et al. 2009, 2013). Additionally, these natural fragments also harbour some grounddwelling species that are more common in open areas, such as $C$. tocantinsi, N. lasiurus and O. fornesi. Since sampling was conducted during the dry season, we believe that these fragments act as a refuge and food resource for these ground-dwelling species, while the terrain is not flooded.

\section{Zoogeographical patterns}

We have attempted to understand the affinities of the natural flooded forest fragments by comparing data on small mammal species assemblages from several sampling sites throughout Cerrado and adjacent biomes. Our hypothesis that the small mammal species composition of these fragments is similar to that of gallery forests of the central-western region of Brazil was supported by our analysis (Figures 3 and 4). At a primary level, the small mammal fauna of ipucas is closely related to that of adjacent forests in the Amazonia-Cerrado ecotone in the state of Tocantins (Passamani 2002; Bezerra et al. 2009; Rocha et al. 2011). However, these latter sites also clustered with sites from western Cerrado and Amazonia-Cerrado and Atlantic Forest-Cerrado ecotones. This region (group II) is a transition between dry areas and moist forested areas in central-western Brazil, which is characterized by the presence of typical Amazonian species, such as $M$. didelphoides, and by typical inhabitants of the Cerrado species, such as C. tocantinsi (Latcher and Allho 2001; Carmignotto 2005; Cáceres et al. 2008; Bezerra et al. 2009; Rocha et al. 2011; Santos-Filho et al. 2012), and also in the southern (site 19) by typical Atlantic Forest species, such as Gracilinanus microtarsus (Cáceres et al. 2008). Thus, these results corroborate the strong influence of moist tropical forested biomes on the natural forest fragments at the Araguaia alluvial plain (Martins et al. 2008).

Additionally, it is noteworthy that several geographical subsets (groups II, III, IV and V) were discriminated in the Cerrado biome concerning small mammal fauna (see also Carmignotto 2005) and that Amazonian sites (group I) and several transitional sites (sites 20, 22 and 29) either clustered separately or did not group with the remaining sampling sites. These geographical subsets in the Cerrado biome encompass the western region (group II), the south-western region (group III), the north-eastern and central region (group IV) and the southeast region (group V). As argued by Carmignotto (2005), zoogeographical patterns observed in the Cerrado are related with the distance to adjacent biomes and their contribution to the small mammal assemblages of this biome. For example, group II has great influence of the Amazonia as mentioned above (Lacher and Alho 2001; Carmignotto 2005; Cáceres et al. 2008; Bezerra et al. 2009; Rocha et al. 2011; Santos-Filho et al. 2012); group III and sites 20 and 22 have great influence of Pantanal and Chaco, accounting with species such as Thylamys macrurus, Marmosa constantiae and Oligoryzomys chacoensis (Carmignotto 2005; Cáceres et al. 2010, 2011; Hannibal and Cáceres 2010; Napoli and Cáceres 2012); group IV accounts with typical and endemic Cerrado species, such as Calomys expulsus, Olygoryzomys moojeni and Rhipidomys macrurus (Mares and Ernest 1995; Bonvicino et al. 2002, 2005; Bonvicino and Bezerra 2003; Carmignotto 2005; Pereira and Geise 2009; Carmignotto and Aires 2011); and finally, group V and site 29 have influence of Atlantic forest, accounting with species such as Marmosops incanus and Philander frenatus (Rodrigues et al. 2002; Carmignotto 2005; Paglia et al. 2005; Gheler-Costa et al. 2012).

These geographical subsets of Cerrado are concordant with previous geographical groupings recognized by Ratter et al. (2003) based on floristic composition (see Figures 5, 6 and 8 from Ratter et al. 2003). These authors argue that despite the considerable overlap in the floristic composition of Cerrado subsets, this biome presents a significant heterogeneity, with large differences among subsets. Furthermore, Faria et al. (2013) found that Serra Geral de Goiás and São Francisco River are important geographic barriers in the Cerrado. The segregation of small mammal communities between groups II and IV, and also within group IV, as revealed by our results, is probably related to those geographic barriers. Although a growing number of studies have been focused on the small mammal fauna in Cerrado (for review see Carmignotto et al. 2012), further studies should be focused on understanding the role of geographic barriers and/or the contribution of different floristic structures within the Cerrado biome to the differentiation of small mammal assemblages (e.g. Nascimento et al. 2011, 2013).

\section{Conservation implications}

Ipucas are closely related to the Amazonia-Cerrado ecotone of central-western region of Brazil, which lies in the so called arc of deforestation (Fearnside and Graça 2006), a region highly susceptible to deforestation and the consequential impacts of human disturbance and agricultural conversion (Morton et al. 2006).

Several authors have already recognized the Araguaia basin as a priority area for conservation, mainly due to its floral and faunal diversity (Cavalcanti and Joly 2002; 
Oliveira-Filho and Ratter 2002; Pinheiro and Dornas 2009; Rocha et al. 2011). Our results emphasize the idea that the habitat mosaic found in the Araguaia alluvial plain has an important role in promoting the high biodiversity of this area and that natural forest fragments within it may act as a refuge and food resource for several species. These fragments may also constitute essential stepping stones for small mammal species in an agricultural landscape. Uezu et al. (2008) have already shown that agro-forest systems favour higher species richness than monoculture systems and that agro-forest patches can potentially act as stepping stones, enabling connectivity in a fragmented landscape.

Conservation efforts in the Araguaia basin should be focused on combining a suitable large mosaic of habitats and providing conditions for a large number of species with different habitat requirements (Ramos Pereira et al. 2013). The long-term persistence of this ecosystem depends on the maintenance of current protected areas and the creation of new ones. Moreover, considering the current debate in Brazil on reconciling agricultural production and environmental conservation (Ferreira et al. 2012), sustainable use reserves will favour not only habitat conservation but also socio-economic interests in this area.

\section{Conclusions}

Seasonally flooded natural forest fragments in the Araguaia alluvial plain represent a peculiar landscape that has not been extensively studied. Ipucas not only harbour species adapted to disturbed habitats and endemic species of the Cerrado but also constitute the most central-eastern distribution limit of one typical Amazonian species (see also Bezerra et al. 2007).

Given the great importance of ipucas in promoting the biodiversity of the Araguaia alluvial plain, further studies are essential to better understand the small mammal communities inhabiting these natural forest fragments. Long-term studies should be directed towards the demographic, behavioural, genetic and ecological responses of small mammal species to fragment size, edge and matrix effects, landscape connectivity and gene flow, which will be very helpful in assessing the future of this fauna and, therefore, in establishing effective conservation practices in this region.

\section{Additional file}

Additional file 1: Gazetteer. List of the decimal geographic coordinates (longitude/latitude) of 31 faunistic study sites used in the similarity analysis. Localities are listed by Brazilian states. References of each sampling site are given after each geographic coordinates.

\section{Competing interests}

The authors declare that they have no competing interests.

\section{Authors' contributions}

RGR and EF designed the study, carried out small mammal sampling and performed the analyses of the data. RGR led the writing. ICMM, LPC and CF obtained funds and logistics to carry on the work and helped to draft the manuscript. All authors read and approved the final manuscript.

\section{Acknowledgements}

We are grateful to the people from Fazenda Lago Verde, Universidade Federal do Tocantins/Fundação de Apoio Científico e Tecnológico do Tocantins (UFT/FAPTO), Ecotropical (a partnership between Instituto Ecológica and Universidade de Aveiro), Universidade Luterana do Brasil (ULBRA-TO) and NATURATINS for all logistic support. RGR and EF were supported by two PhD grants from Fundação Ciência e Tecnologia (Program POPHQREN, ref: SFRH/BD/24767/2005 and SFRH/BD/23191/2005,

respectively). RGR and LPC have research grants from Conselho Nacional de Desenvolvimento Científico e Tenológico (CNPq, Brazil). This work was co-supported by European Funds through COMPETE and by National Funds through the Portuguese Science Foundation (FCT) within project PEst-C/ MAR/LA0017/2013.

\section{Author details}

${ }^{1}$ Departamento de Biologia and CESAM, Universidade de Aveiro, Campus de Santiago, 3810-193 Aveiro, Portugal. ' Laboratório de Mastozoologia e Biogeografia, Departamento de Ciências Biológicas, Universidade Federal do Espírito Santo, Av. Marechal Campos 1468, Maruípe, 29043-900 Vitória, Espírito Santo, Brasil. ${ }^{3}$ Laboratório de Caracterização e Impacto Ambiental, Universidade Federal do Tocantins, 109 Norte, Av. NS 15, ALCNO 14,

77001-090 Palmas, Tocantins, Brazil.

Received: 2 April 2014 Accepted: 26 August 2014

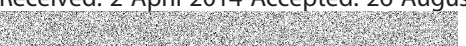

\section{References}

Ackerly DD, Thomas WW, Ferreira CAC, Pirani JR (1989) The forest-Cerrado transition zone in Southern Amazonia: results of the 1985 Projeto Amazonica expedition to Mato Grosso. Brittonia 41:113-128

Barros-Battesti DM, Martins R, Bertim CR, Toshinari NH, Bonoldi VLN, Leon EP, Miretzki M, Schumaker TTS (2000) Land fauna composition of small mammals of a fragment of Atlantic Forest in the State of São Paulo, Brazil. Rev Bras Zool 17:241-249

Beja PC, Santos D, Santana J, Pereira MJ, Marques JT, Queiroz HL, Palmeirim JM (2009) Seasonal patterns of spatial variation in understory bird assemblages across a mosaic of flooded and unflooded Amazonian Forests. Biodivers Conserv 19:129-152

Bezerra AMR, da Silva Jr NJ, Marinho-Filho J (2007) The amazon bamboo rat Dactylomys dactylinus (Rodentia: Echimydae: Dactylomyinae) in the Cerrado of Central Brazil. Biota Neotrop 7:235-237

Bezerra AMR, Carmignotto AP, Rodrigues FHG (2009) Small non-volant mammals of an ecotone region between the Cerrado hotspot and the Amazonian rainforest, with comments on their taxonomy and distribution. Zool Stud 48:861-874

Bonvicino CR, Bezerra AMR (2003) Use of regurgitated pellets of Barn Owl (Tyto alba) for inventorying small mammals in the Cerrado of central Brazil. Stud Neotrop Fauna E 38:1-5

Bonvicino CR, Cerqueira R, Soares VA (1996) Habitat use by small mammals of upper Araguaia river. Rev Bras Biol 56:761-767

Bonvicino CR, Lindbergh SM, Maroja LS (2002) Small non-flying mammals from conserved and altered areas of Atlantic Forest and Cerrado: comments on their potential use for monitoring environment. Braz J Biol 62:765-774

Bonvicino CR, Lima JFS, Almeida FC (2003) A new species of Calomys Waterhouse (Rodentia, Sigmodontinae) from the Cerrado of Central Brazil. Rev Bras Zool 20:301-307

Bonvicino CR, Lemos B, Weksler M (2005) Small mammals of Chapada do Veadeiros National Park (Cerrado of central Brazil): ecological, karyological, and taxonomic considerations. Braz J Biol 65:395-406

Bonvicino CR, Oliveira JA, D'Andrea PS (2008) Guia dos roedores do Brasil com chaves para géneros baseadas em caracteres externos. Centro Pan-Americano de Febre Aftosa-OPAS/OMS, Rio de Janeiro

Cáceres NC, Casella J, Vargas CF, Prates LZ, Tombini AAM, Goulart GS, Lopes WH (2008) Distribuição geográfica de pequenos mamíferos não voadores nas bacias dos rios Araguaia e Paraná, região centro-sul do Brasil. Iheringia Ser Zool 98:173-180 
Cáceres NC, Nápoli RP, Casella J, Hannibal W (2010) Mammals in a fragmented savannah landscape in south-western Brazil. J Nat Hist 44:491-521

Cáceres NC, Godoi MN, Hannibal W, Ferreira VL (2011) Effects of altitude and vegetation on small-mammal distribution in the Urucum Mountains, western Brazil. J Trop Ecol 27:279-287

Carmignotto AP (2005) Pequenos mamíferos terrestres do bioma Cerrado: padrões faunísticos locais e regionais. PhD Thesis. University of São Paulo

Carmignotto AP, Aires CC (2011) Mamíferos não voadores (Mammalia) da Estação Ecológica Serra Geral do Tocantins. Biota Neotrop 11:313-328

Carmignotto AP, de Vivo M, Langguth A (2012) Mammals of the Cerrado and Caatinga: distribution patterns of the tropical open biomes of Central South America. In: Patterson B, Costa LP (eds) Bones, Clones and Biomes: The History and Geography of Recent Neotropical Mammals. The University of Chicago Press, Chicago \& London

Cavalcanti RB, Joly CA (2002) Biodiversity and conservation priorities in the Cerrado region. In: Oliveira PA, Marquis RJ (eds) The Cerrados of Brazil, Ecology and Natural History of a Neotropical Savanna. Columbia University Press, New York

Chao A (1984) Non-parametric estimation of the number of classes in a population. Scand J Stat 11:265-270

Clarke KR, Gorley RN (2006) PRIMER v6: User Manual/Tutorial. PRIMER-E, Plymouth

Clarke KR, Somerfield PJ, Gorley RN (2008) Testing of null hypotheses in exploratory community analyses: similarity profiles and biota-environment linkage. J Exp Mar Biol Ecol 366:56-69

Colwell RK (2013) EstimateS: statistical estimation of species richness and shared species from samples. Version 9. User's Guide and application., Available via EstimateS http://purl.oclc.org/estimates. Accessed 25 March 2014

D'Andrea PS, Gentile R, Maroja LS, Fernandes FA, Coura R, Cerqueira R (2007) Small mammal populations of an agroecosystem in the Atlantic Forest domain, southeastern Brazil. Braz J Biol 67:179-186

Eiten G (1985) Vegetation near Santa Teresinha, NE Mato Grosso. Acta Amazonica 15:275-301

Emmons LH, Feer F (1997) Neotropical Rainforest Mammals, 2nd edn. The University of Chicago Press, Chicago

Faria MB, Nascimento F, de Oliveira JA, Bonvicino CR (2013) Biogeographic Determinants of Genetic Diversification in the Mouse Opossum Gracilinanus agilis. Didelphidae, Didelphimorphia. doi:10.1093/jhered/est039

Fearnside PM, Graça PMLA (2006) BR-319: Brazil's Manaus-Porto Velho highway and the potential impact of linking the arc of deforestation to central Amazonia. Environ Manage 38:705-716

Ferreira J, Pardini R, Metzger JP, Fonseca CR, Pompeu PS, Sparovek G, Louzada J (2012) Towards environmentally sustainable agriculture in Brazil: challenges and opportunities for applied ecological research. J Appl Ecol 49:535-541

Gardner AL (2008) Mammals of South America, vol 1. Marsupials, xenarthrans, shrews, and bats. The Chicago University Press, Chicago

Gheler-Costa C, Vettorazzi CA, Pardini R, Verdade LM (2012) The distribution and abundances of small mammals in agroecosystems of southeastern Brazil. Mammalia 76:185-191

Hannibal W, Cáceres NC (2010) Use of vertical space by small mammals in gallery forest and woodland savannah in south-western Brazil. Mammalia 74:247-255

Haugaasen T, Peres CA (2005) Primate assemblage structure in Amazonian flooded and unflooded forests. Am J Primatol 67:243-258

Hayek LAC, Buzas MA (1997) Surveying Natural Populations. Columbia University Press, New York

INMET (2011) Instituto Nacional de Metereologia, Brazil., Available via http://www. inmet.gov.br. Accessed in 14 March 2011

IUCN (2013) IUCN Red List of Threatened Species. Version 2012.2., Available via IUCN. www.iucnredlist.org. Accessed 25 March 2014

Lacher TE, Alho CJR (2001) Terrestrial small mammal richness and habitat associations in an Amazon forest-Cerrado contact zone. Biotropica 33:171-181

Lambert TD, Malcolm JR, Zimmerman BL (2006) Amazonian small mammal abundances in relation to habitat structure and resource abundance. J Mammal 87:766-776

Mares MA, Ernest KA (1995) Population and community ecology of small mammals in a gallery forest of Central Brazil. J Mammal 76:750-768

Marinho-Filho J, Vieira E, D'Elia G, Pardinas U (2008) Necromys lasiurus. In: IUCN 2013. IUCN Red List of Threatened Species. Version 2013.2., Available via IUCN. www.iucnredlist.org. Accessed 25 March 2014
Martins ICM, Soares VP, Silva E, Brites RS (2002) Diagnóstico ambiental no contexto da paisagem de fragmentos florestais naturais "Ipucas" no município de Lagoa da Confusão, Tocantins. Revista Árvore 26:299-309

Martins AKE, Schaefer CEGR, Silva E, Soares VP, Corrêa GR, de Mendonça BAF (2006) Relações solo-geoambientais em áreas de ocorrência de ipucas na planície do médio Araguaia - Estado de Tocantins. Revista Árvore 30:297-310

Martins SV, Brito ER, Oliveira-Filho AT, da Silva AF, Silva E (2008) Floristic composition of two wetland forests in Araguaian plain, State of Tocantins, and comparison with other areas. Revista Árvore 34:129-141

Morton DC, DeFries RS, Shimabukuros YE, Anderson LO, Arai E, Bon Espirito-Santo F, Freitas R, Morisette J (2006) Cropland expansion changes deforestation dynamics in the southern Brazilian Amazon. Proc Natl Acad Sci 103:14637-14641

Napoli RP, Cáceres NC (2012) Absence of edge effect on small mammals in woodland-savannah remnants in Brazil. Community Ecol 13:11-20

Nascimento FF, Pereira LG, Geise L, Bezerra AMR, D'Andrea PS, Bonvicino CR (2011) Colonization process of the Brazilian common vesper mouse, Calomys expulsus (Cricetidae, Sigmodontinae): a biogeographic hypothesis. J Hered 102:260-268

Nascimento FF, Lazar A, Menezes AN, Durans AM, Moreira JC, Salazar-Bravo J, D'Andrea PS, Bonvicino CR (2013) The role of historical barriers in the diversification processes in open vegetation formations during the Miocene/Pliocene using an ancient rodent lineage as model. PloS One 8:e61924

Oliveira-Filho AT, Ratter JA (2002) Vegetation physiognomies and woody flora of the Cerrado biome. In: Oliveira PA, Marquis RJ (eds) The Cerrados of Brazil, Ecology and Natural History of a Neotropical Savanna. Columbia University Press, New York

Paglia AP, Lopes MOG, Perini FA, Cunha HM (2005) Mammals of the Estação de Preservação e Desenvolvimento Ambiental de Peti (EPDA-Peti), São Gonçalo do Rio Abaixo, Minas Gerais, Brazil. Lundiana 6:89-96

Paglia AP, Fonseca GAB, Rylands AB, Herrmann G, Aguiar LMS, Chiarello AG, Leite YLR, Costa LP, Siciliano S, Kierulff MCM, Mendes SL, Tavares VC, Mittermeier RA, Patton JL (2012) Lista Anotada dos Mamíferos do Brasil / Annotated Checklist of Brazilian Mammals, 2a Edição / 2nd edn. Occasional Papers in Conservation Biology, No. 6. Conservation International, Arlington

Passamani M (2002) Levantamento de pequenos mamíferos não-voadores da região centro do Tocantins. Humanitas 4:55-62

Percequillo A, Patton J, Pires-Costa L, D'Elia G, Patterson B (2013) Hylaeamys megacephalus. In: IUCN (ed) IUCN Red List of Threatened Species. Version 2013.2., Available via IUCN. www.iucnredlist.org. Accessed 25 March 2014

Pereira LP, Geise L (2009) Non-flying mammals of Chapada Diamantina (Bahia, Brazil). Biota Neotrop 9:185-196

Pinheiro RT, Dornas T (2009) Bird distribution and conservation on Cantão region, State of Tocantins: Amazon/Cerrado ecotone. Biota Neotrop 9:187-205

Ramos Pereira MJ, Marques JT, Santana J, Santos CD, Valsecchi J, de Queiroz HL, Beja P, Palmeirim JM (2009) Structuring of Amazonian bat assemblages: the roles of flooding patterns and floodwater nutrient load. J Anim Ecol 78:1163-1171

Ramos Pereira MJ, Rocha RG, Ferreira E, Fonseca C (2013) Structure of small mammal assemblages across flooded and unflooded gallery forests of the Amazonia-Cerrado ecotone. Biotropica 45:489-496

Ratter JA (1992) Transitions between Cerrado and forest vegetation in Brazil. In: Furley PA, Proctor J, Ratter JA (eds) Nature and Dynamics of Forest-Savanna Boundaries. Chapman \& Hall, London

Ratter JA, Bridgewater SB, Ribeiro JF (2003) Analysis of the floristic composition of the Brazilian Cerrado vegetation III: comparison of the woody vegetation of 376 areas. Edinb J Bot 60:57-109

Ribeiro R, Marinho-Filho J (2005) Estrutura da comunidade de pequenos mamíferos (Mammalia, Rodentia) da Estação Ecológica de Águas Emendadas, Planaltina, Distrito Federal, Brasil. Rev Bras Zool 22:898-907

Rocha RG, Ferreira E, Oliveira BMA, Martins ICM, Leite YLR, Costa LP, Fonseca C (2011) Small mammals of the mid-Araguaia river in Central Brazil, with the description of a new species of climbing rat. Zootaxa 2789:1-34

Rodrigues FHG, Silveira L, Jácomo ATA, Carmignotto AP, Bezerra AMR, Coelho DC, Garbogini H, Pagnozzi J, Hass A (2002) Composição e caracterização da fauna de mamíferos Parque Nacional das Emas, Goiás, Brasil. Rev Bras Zool 19:589-600

Santos-Filho M, Frieiro-Costa F, Ignácio ÁRA, Silva MNF (2012) Use of habitats by non-volant small mammals in Cerrado in Central Brazil. Braz J Biol 72:893-902

Uezu A, Beyer DD, Metzger JP (2008) Can agroforest woodlots work as stepping stones for birds in the Atlantic forest region? Biodivers Conservat 17:1907-1922 
Umetsu F, Pardini R (2007) Small mammals in a mosaic of forest remnants and anthropogenic habitats - evaluating matrix quality in an Atlantic forest landscape. Landsc Ecol 22:517-530

Weksler M (2006) Phylogenetic relationships of Oryzomine Rodents (Muroidea: Sigmodontinae): separate and combined analyses of morphological and molecular data. Bull Am Mus Nat Hist 296:1-149

Wilson DE, Reeder DA (2005) Mammal Species of the World: A Geographic and Taxonomic Reference, 3rd edn. John Hopkins University Press, Baltimore

doi:10.1186/s40555-014-0060-0

Cite this article as: Rocha et al: Seasonally flooded stepping stones: emerging diversity of small mammal assemblage in the AmazoniaCerrado ecotone, central Brazil. Zoological Studies 2014 53:60.

Submit your manuscript to a SpringerOpen ${ }^{\circ}$ journal and benefit from:

- Convenient online submission

- Rigorous peer review

- Immediate publication on acceptance

- Open access: articles freely available online

- High visibility within the field

- Retaining the copyright to your article 